\title{
Nude Mouse Assay
}

National Cancer Institute

\section{Source}

National Cancer Institute. Nude Mouse Assay. NCI Thesaurus. Code C19351.

Any bioassay using a nude mouse. 